\title{
A Review of the Relationship Among Parenting Practices, Parenting Styles, and Adolescent School Achievement
}

\author{
Christopher Spera ${ }^{1,2}$
}

\begin{abstract}
This article reviews the literature on the relationship among parenting practices, parenting styles, and adolescent school achievement. The review of the empirical research indicates that parental involvement and monitoring are robust predictors of adolescent achievement. Several studies, however, indicate that parental involvement declines in adolescence, prompting the call for future research on the reasons for and associated consequences of this decline. Furthermore, the review indicates that authoritative parenting styles are often associated with higher levels of student achievement, although these findings are not consistent across culture, ethnicity, and socioeconomic status. Darling and Steinberg's contextual model of parenting provides a promising model to help resolve these discrepancies, however, further research is needed to examine the major linkages of the model. It is also argued that the contextual model should expand its notion of context towards the larger cultural and economic context in which families reside.
\end{abstract}

KEY WORDS: parenting styles; parenting practices; adolescence; socioeconomic status; academic achievement.

Theories about how parental values, goals, skills, and attitudes are passed from one generation to the next have been debated by philosophers since the seventeenth century. For example, in his Essay Concerning Human Understanding, John Locke (1689) posited that children were born with a "tabula rasa" or a blank slate by which parents and society could easily transmit their values and beliefs to their children. In contrast, Jean

\footnotetext{
${ }^{1}$ University at Albany, State University of New York, Albany, New York.

${ }^{2}$ Correspondence should be addressed to Christopher Spera, University at Albany, State University of New York, Albany, New York; e-mail: cspera@uamail.albany.edu.
} 
Jacques Rousseau (1762) believed that children were born "innately good" and that it is up to parents and society to uphold and further teach the values inherent in children. Similar to the philosophers from centuries ago, educational and developmental psychologists of today are interested in gaining a better understanding of the interactive socialization process by which parents attempt to transmit their values, goals, skills, and attitudes to their children (see Grusec, 1997; Parke and Buriel, 1998).

The process of socialization refers to the manner by which a child, through education, training, observation, and experience, acquires skills, motives, attitudes, and behaviors that are required for successful adaptation to a family and a culture (Parke and Buriel, 1998; Ladd and Pettit, 2002). The socialization process is bidirectional in that parents convey socialization messages to their children, but their children vary in their level of acceptance, receptivity, and internalization of these messages (Grusec et al., 2000).

Within the socialization literature, recent attention has been given to examining linkages between the child's home environment (i.e., family) and the child's school environment (see Ryan and Adams, 1995; Scaringello, 2002). Within these two developmental contexts, adolescents interact with and are influenced by multiple socialization agents, including their parents, teachers, and peers (Maccoby and Martin, 1983; Parke and Buriel, 1998; Wentzel, 1999). Adolescence is a particular period of human development in which the interface of the school and home contexts gain critical importance (Paulson, 1994; Steinberg and Silk, 2002). During this period, adolescents transition from the highly dependent and controlled period of childhood into a period marked by an increasing sense of self-exploration and autonomy (Wentzel and Battle, 2001). Specifically, adolescents begin to develop their self-concept (Harter, 1983) and explore their relationship and connection to family, friends, and the larger society (Simmons et al., 1987). As a result, adolescence is not only a time of change for adolescents, but it is also a time of change for the family unit (Kreppner, 1992).

Several theories have organized and examined the research on adolescent family-school linkages (e.g., Bronfenbrenner, 1979; Grusec, 2002; Wentzel, 1999). In this article, Darling and Steinberg's (1993) contextual model of parenting is used as an overarching framework to examine the relationship among parenting practices, parenting styles, and adolescent school outcomes. The article first reviews the historical and current literature on parenting practices and parenting styles as they relate to adolescent school achievement. The article then examines the consistency of the research findings focusing on the relationship between parenting styles and adolescent school outcomes across families from diverse ethnic and socioeconomic backgrounds. Finally, the article considers whether the contextual 
model of parenting (Darling and Steinberg, 1993) can help resolve the discrepancies in the literature. In this last section, empirical support for each of the major tenets in the contextual model is offered and recommendations to expand the model to include additional contextual variables are provided.

\section{PARENTING STYLES AND PARENTING PRACTICES}

In the last 25 years, a myriad of studies on the family-school connection have examined the influence of distinct types of parenting styles (e.g., typologies characterized by responsiveness and demandingness) and specific parental practices (e.g., monitoring of after school activities, helping with homework, attending parent-teacher conferences) on student school-based outcomes (see Scott-Jones, 1995). In describing their studies, researchers have often used the labels parenting styles and parenting practices interchangeably (Maccoby and Martin, 1983); however, Darling and Steinberg (1993) suggest that to better understand the socialization process it is important to distinguish between parenting practices and parenting styles.

Parenting practices are defined as specific behaviors that parents use to socialize their children (Darling and Steinberg, 1993). For example, when socializing their children to succeed in school, parents might enact certain practices such as doing homework with their children, providing their children with time to read, and attending their children's school functions. In contrast, Darling and Steinberg (1993) define a parenting style as the emotional climate in which parents raise their children. Parenting styles have been characterized by dimensions of parental responsiveness and demandingness (Baumrind, 1991). In the sections that follow, the historical and current literature on parenting styles and parenting practices is reviewed. The Darling and Steinberg (1993) distinction between parenting styles and parenting practices is used to classify studies within each domain.

\section{Parenting Practices}

The research on parenting practices as they relate to adolescent school outcomes has focused on several important parenting constructs. These constructs include parental involvement; parental monitoring; and parental goals, values, and aspirations. A review of the research on each of these parenting constructs is presented below. The review focuses on adolescence and, where applicable, on preadolescent children to point out differences in the research findings for adolescent versus preadolescent children. 


\section{The Role of Parental Involvement}

Interacting and becoming involved with their children's life on a daily basis is a way parents can socialize their children. With respect to the socialization of school achievement, parental involvement consists of attending parent-teacher conferences, helping children with homework, volunteering for leadership roles within the school, and attending children's extracurricular activities. Epstein and colleagues have distinguished between parental involvement practices that are initiated by parents and parental involvement practices that are initiated by schools (see Epstein, 1996; Epstein and Connors, 1994; Epstein and Dauber, 1991; Epstein and Lee, 1995).

Involvement practices initiated by parents represent parental efforts to become directly involved with school decisions and activities. For example, parent-initiated involvement practices include parents serving on school boards or parent organizations. They also include ways parents get involved with their children's school-related activities within the home, such as helping their children with homework. On the other hand, school-initiated involvement practices represent efforts by the school to provide parents with routine information about school policies, procedures, and events, as well as their children's progress. School-initiated involvement practices also include efforts by the school to announce parent opportunities to participate on school boards, committees, and parent organizations.

Researchers have found a strong positive relationship between parentinitiated involvement practices and school outcomes (see Epstein and Sanders, 2002; Hess and Holloway, 1984; Hill et al., in press). For example, researchers have found that higher levels of parent-initiated involvement, such as parent attendance of school activities, open-school nights, and parent-teacher conferences, are related positively to elementaryschool-aged children's school performance (e.g., Becker and Epstein, 1982; Stevenson and Baker, 1987). Moreover, studies with adolescents have found that parental assistance with homework is positively related to the amount of time adolescents spend on their homework (Hewison, 1988; Keith et al., 1986; Muller and Kerbow, 1993). Similarly, researchers have found a strong positive relationship between school-initiated parental involvement practices and children's school outcomes (see Greenwood and Hickman, 1991). For example, Hoover-Dempsey et al. (1987) found that higher levels of teacher communication with parents of middle school children were positively related to parents' attendance of parent-teacher conferences and school activities.

Despite these positive relations between parental involvement practices and school-related outcomes, researchers have found that parental involvement declines in adolescence (Milgram and Toubiana, 1999; Muller, 
1998). For example, Epstein and Dauber (1991) found that the level of parental involvement with school activities was stronger in elementary school than middle school. Similarly, a recent National Household Education Survey conducted by the U.S. Department of Education (1998) found that the provision of opportunities by schools for parents to participate in school activities declined in middle school.

An analysis of the National Educational Longitudinal Study (NELS: 1988) has provided rich information on the potential decline of schoolinitiated and parent-initiated involvement during adolescence. With respect to school-initiated involvement practices, analyses of the NELS: 1988 database found that a large proportion of parents reported that schools do not initiate contact with them directly to seek their participation in school activities or to update them on their child's progress (Epstein and Lee, 1995). Specifically, the study found that approximately $60 \%$ of parents of eighth-grade students reported that the school does not contact them seeking information about their child (Epstein and Lee, 1995). Approximately $65 \%$ of parents reported that the school has not contacted them about their child's academic program or progress. Furthermore, over $70 \%$ of parents indicated that they have never been asked by their child's school to volunteer in school. Results on parent-initiated involvement practices were mixed. Specifically, over $80 \%$ of parents indicated that they talk to their children regularly about their school progress, however only about half $(56 \%)$ indicated that they regularly help their child with homework.

Further research is needed to examine why parental involvement in adolescence is declining and to understand the consequences of that decline. Some researchers have suggested that the decline stems from parents' recognition of an increased need for adolescents to express their autonomy (see Ryan and Stiller, 1991; Steinberg, 1990). As noted by Wentzel and Battle (2001), "a hallmark of adolescent development is gaining emotional and psychological independence from family (p. 95)." As a result of an increased need for autonomy, adolescents might respond negatively to high levels of parental involvement. Still, the decline in parental involvement might be too much. Therefore, a promising next step in the research on parental involvement in adolescence is to identify the threshold or cutoff between a healthy and unhealthy level of parental involvement. The latter may be a case of what might be called 'over-involvement.' Of course it likely that the threshold may vary for children with different temperaments and personalities, so the research should examine the influence of these factors too.

It also remains unclear whether parental involvement in adolescence declines for all parents or only certain subpopulations of parents. For example, parental involvement in adolescence may remain strong for parents 
with children who have disciplinary or academic problems compared to parents with children who lack such difficulties (see Hill, 2001). These possibilities highlight the need for researchers to gather information on the reasons behind parental involvement (e.g., for disciplinary concerns versus nurturing a gifted student). The traditional measures used to examine parental involvement, however, do not attain the reasons for parental involvement (Hill and Taylor, 2004). The development or modification of instruments to gather this kind of information seems warranted.

\section{The Role of Parental Monitoring}

Another way for parents to be involved in the education of their children is to monitor their after-school activities, such as monitoring the completion of homework, supervising activities with peers, and checking on school progress. Researchers have found that parental involvement with and monitoring of homework is related to adolescents' completion of homework (e.g., Muller and Kerbow, 1993). Analyses of the NELS: 1988 database indicated, however, that less than half (45\%) of parents of adolescents checked homework often (Epstein and Lee, 1995).

In addition to the monitoring of homework, research suggests that parental monitoring of after school activities is related to student achievement. For example, Clark (1993) found that parents of children who monitor their children's behavior after school were more likely to have high achieving children than parents who do not monitor their children's afterschool activities. Furthermore, Muller (1993) found that parents' knowledge of their adolescent's friends was positively related to their child's standardized achievement scores.

Despite the strong association between parental monitoring and adolescent school outcomes, one wonders why less than half of parents of adolescents check homework often. Issues related to the influence of parental work hours and multiple jobs should be examined with respect to their influence on parental monitoring (see Hill and Taylor, 2004). Furthermore, examining the reasons for parental monitoring (e.g., because of child misbehavior) may also lead to a fuller understanding of the relation of parental monitoring to adolescent school outcomes.

\section{The Role of Parental Goals, Values, and Aspirations}

A primary way parents socialize their children is by communicating the goals they want their children to attain, the aspirations they want their children to fulfill, and the values they want their children to internalize. 
Parental goals and aspirations are best described as internal representations of desired states or outcomes that parents hold for their children. These, in turn, organize and direct parents' behaviors toward their children (see Austin and Vancouver, 1996; Wentzel, 1998). Parental values toward education represent the importance parents place on their children's educational achievement (see Bandura, 1989; Eccles and Wigfield, 1995; Ford, 1992). With respect to school achievement, parents might set certain goals and hold certain aspirations for their children, such as doing well in math class, graduating high school, and attending college. Similarly, parents might communicate to their children their values with respect to school (i.e., importance of education), intending for their children to adopt these values and beliefs.

Researchers have found that parental aspirations, goals, and values are related to their children's setting of academic goals, persistence in school, course enrollment, intellectual accomplishments, and attendance of college (Astone and McLanahan, 1991; Crandall et al., 1964; Keeves, 1972; Pugh, 1976). Researchers have also found that parents' values towards education relate to their children's educational attainment, persistence, and performance (Eccles et al., 1983; Lee, 1985; Prom-Jackson, 1987; Wigfield, 1993).

Several studies have examined the extent to which parental aspirations, goals, and values for their children's educational attainment vary by parents' ethnicity. Researchers have found that African American and Hispanic parents place a high value on education, are concerned with educational issues, and have educational aspirations for their children that equal those of nonminority parents (De La Rosa and Maw, 1990; Stevenson et al., 1990; Wentzel, 1998). Despite these findings, recent data from the U.S. Bureau of Census (2004) indicates that a smaller percentage of African Americans and Hispanics attain a college degree than Caucasians. Furthermore, researchers have found that Hispanics and African Americans have higher drop-out rates from high school and lower levels of educational attainment than Caucasian students (De La Rosa and Maw, 1990; Goldenberg, 1987; Hodgkinson, 1992; Kao and Tienda, 1995; Richardson and Gerlach, 1980; Soloranzo, 1992).

These findings raise important questions as to whether minority students and their parents are given equal educational opportunities to realize their aspirations (Soloranzo, 1992). Despite the strong value minority parents place on education, it is also possible they do not have the educational experiences to draw upon to help foster their children's educational attainment on a day-to-day basis (see Entwisle and Hayduk, 1982; Seginer, 1983). As a result, future research should focus on parental intervention strategies and programs designed to help minority parents translate their strong values towards education into everyday parenting practices. 


\section{Parenting Styles}

This section presents an overview of the relevant literature on parenting styles. It begins with the early work on the study of parental disciplinary styles and parental typologies and follows with more current theory and research. The earliest research on parenting and its influence on child development examined ways in which parents discipline their children. Early pioneers, such as Robert Sears, Elanor Maccoby, and Martin Hoffman, set the stage for research in this area. Their work is still well cited and relevant to the research today.

\section{Love-Oriented Versus Object-Oriented Styles}

In the mid to late 1950s, Robert Sears and Eleanor Maccoby documented patterns and processes of child rearing through intense one-on-one interviews with parents (see Grusec, 1997; Maccoby and Martin, 1983). In their publication, Patterns of Child Rearing (Sears et al., 1957), Sears and colleagues reported on findings from over 300 interviews with mothers. In this research, mothers were asked about their child-rearing practices including their style and use of disciplinary techniques. Based on analyses of these qualitative data, Sears and his colleagues classified maternal disciplinary techniques into one of two distinct types: love-oriented and object-oriented.

The love-oriented style, as described by Sears et al. (1957), consisted of maternal use of warmth, praise, and emotional affection (and withdrawal of these) to respond to their children's behaviors. The object-oriented style consisted of maternal use (and withdrawal) of tangible objects, such as toys or extra playtime, to respond to their children's behavior. In examining the effects of these disciplinary styles on child development, Sears et al. (1957) found that these disciplinary styles uniquely impacted children's internalization of their parents' values. Specifically, they found that children of parents who used a love-oriented disciplinary approach were more likely to internalize the values of their parents (i.e., take on the values as their own) than children of parents who used an object-oriented disciplinary style. They also found that parental use of love-oriented strategies was associated with children's display of self-control and self-regulation.

When interpreting their findings, Sears et al. (1957) suggested that children who are exposed to object-oriented disciplinary techniques following a misdeed spend their cognitive and physical energy trying to avoid object withdrawal (e.g., their parents taking away a privilege). As a result of spending their energy trying to avoid object withdrawal, these children do not exert sufficient cognitive effort to understand their parents' actions and, 
as a result, do not internalize their parents' values. On the other hand, children who are exposed to love-oriented disciplinary techniques gain a better understanding of their parents' rationale for provision or withdrawal of love and as a result internalize their parents' values.

\section{Parental Use of Induction in Their Disciplinary Style}

In his review of the literature on parental disciplinary techniques, Martin Hoffman (1970) pointed out that disciplinary strategies might or might not include what he called "induction." He defined induction as parents' provision of explanations (i.e., reasoning) with respect to their actions, values, and disciplinary behaviors. Hoffman suggested that parents' use of induction encourages children to focus on learning the reasons behind their parents' actions. Furthermore, he pointed out that parents' reasoning with respect to their disciplinary actions might include explanations of the influence of the child's behavior on other people, which Hoffman called "otheroriented induction." He contended that other-oriented induction enables children to realize the influences and consequences of their behaviors on others (e.g., peers, siblings, teachers).

Hoffman (1970) concluded that parental use of induction was positively related to children's internalization of parental values (defined as moral judgements depicting an internal versus external orientation) and to their development of altruism and moral reasoning. He suggested that parents' explanations of their actions to their children help them better understand their parents' cognitive thought processing, thus facilitating the transfer of values from parent to child. In addition, he suggested that otheroriented induction techniques (i.e., the child's realization of their influence on others) facilitate children's development of empathy.

Later in his career, Hoffman (1983) advocated for a parental disciplinary model that combines power-assertion and induction (used in the proper sequence) to maximize the model's positive influence on child development. The model advocates using power assertion at the outset to get the child's attention and then using induction. This model is particularly effective when children commit misdeeds such as lying and stealing (Grusec et al., 1982).

\section{Parenting Style Typologies}

Early work on parenting styles examined a myriad of dimensions including: responsiveness/unresponsiveness (Baldwin, 1948; Freud, 1933; Rogers, 1960; Sears et al., 1957; Schaefer, 1959), democratic/autocratic 
(Baldwin, 1948), emotionally involved/uninvolved (Baldwin, 1948), control/noncontrol (Schaefer, 1959), acceptance/rejection (Symonds, 1939), dominance/submission (Symonds, 1939), and restrictiveness/permissiveness (Becker, 1964). Studies conducted by these early researchers found that parents who provide their children with nurture (also described as warmth, responsiveness), independence (also described as democratic), and firm control had children with higher levels of competence and social adeptness (see Baldwin, 1948; Sears et al., 1957).

Following this early work, Diana Baumrind conducted extensive observations and interviews with parents that resulted in the most well-known and influential typological approach (Baumrind, 1971,1978, 1989). Through multiple studies, Baumrind identified three primary parental typologies: authoritative, authoritarian, and permissive. Baumrind (1978) suggested that authoritative parents are warm and responsive, providing their children with affection and support in their explorations and pursuit of interests. These parents have high maturity demands (e.g., expectations for achievement) for their children but foster these maturity demands through bidirectional communication, induction (i.e., explanations of their behavior), and encouragement of independence. For example, when socializing their children (e.g., to do well in school), these parents might provide their children with a rationale for their actions and priorities (e.g., "it will allow you to succeed as an adult."). Authoritative parents score high on measures of warmth and responsiveness and high on measures of control and maturity demands (Maccoby and Martin, 1983).

Baumrind (1978) suggested that authoritarian parents are neither warm nor responsive to their children. They have high maturity demands for their children primarily because they are intolerant of selfishness or inappropriate behavior. These parents are strict, expect obedience, and assert power when their children misbehave. When socializing their children, authoritarian parents express their maturity demands and expectations through rules and orders, and do not communicate to their children the rationale behind these rules. For example, authoritarian parents might insist, "you better do well in school. . .because I said so." These parents score high on measures of maturity demands and control but low on measures of responsiveness, warmth, and bidirectional communication (Maccoby and Martin, 1983).

Baumrind (1978) suggested that permissive parents are moderate in their responsiveness (i.e., some parents are high and some are low) toward their children's needs. These parents, however, are excessively lax in their expectations for their children's level of maturity and their tolerance of misbehavior. When socializing their children, permissive parents are usually dismissive and unconcerned. These parents score moderately high on 
measures of responsiveness and low on measures of maturity demands and control (Maccoby and Martin, 1983). In review of and reflection on the literature, Maccoby and Martin (1983) added a fourth dimension to the Baumrind typology: indulgent. They described indulgent parents as similar to permissive parents in their level of control and maturity demands but different than permissive parents in their level of responsiveness and warmth. Indulgent parents score low on measures of responsiveness, warmth, and control.

After consistent documentation of these styles, Baumrind (1991) factor analyzed data on these typologies and reduced parenting styles into two dimensions: demandingness and responsiveness. Demandingness refers to the demands parents make on their children to become integrated into the family and the society. Aspects of parental demandingness include the extent to which parents hold maturity demands for their children, provide supervision, and enact disciplinary efforts when needed (Baumrind, 1991). Responsiveness refers to parental behaviors that intentionally foster individuality, self-regulation, and self-assertion in their children. Aspects of parental responsiveness include the extent to which parents are sensitive toward and supportive of their children (Baumrind, 1991).

\section{THE RELATION OF PARENTING STYLES TO ADOLESCENT SCHOOL OUTCOMES: ARE THE FINDINGS UNIVERSAL?}

A host of research studies have found a positive relationship between authoritative parenting styles and student achievement (e.g., Baumrind, 1967; Dornbusch et al., 1987; Lamborn et al., 1991; Steinberg et al., 1989; Steinberg et al., 1991). One of the first studies to report this relationship was conducted by Baumrind (1967). Following a longitudinal sample of children from preschool through adolescence, Baumrind found that preschool children of authoritative parents were more mature, independent, prosocial, active, and achievement-oriented than children of nonauthoritative parents. On the other hand, preschool children of permissive parents scored lowest on measures of self-reliance, self-control, and competence. To examine whether these findings were stable across time, Baumrind again examined the relationship between parenting styles and school achievement during adolescence. She found that parenting styles and their relationship to school outcomes was consistent with the earlier preschool findings (Baumrind, 1989).

Following Baumrind's early work, Dornbusch, Steinberg, and their colleagues conducted a series of studies to explore the influence of parenting styles on adolescent achievement. These studies used data from large-scale 
surveys of over 6000 adolescents in Wisconsin and California. One of the first studies in this series found that parents who displayed higher levels of authoritative parenting by providing their children with warmth, autonomy, and high maturity demands had children with higher achievement levels (Steinberg et al., 1989). In another study, Steinberg et al. (1992) found that authoritative parenting was related to adolescent grade point average (GPA) and school engagement.

These findings have led researchers to ask why authoritative parenting styles are associated with positive school outcomes. In a review of these findings, Durkin (1995) cites three reasons why authoritative parenting might be related to positive child outcomes. First, he suggests that authoritative parents provide a high level of emotional security that provides their children with a sense of comfort and independence and helps them succeed in school. Second, he suggests that authoritative parents provide their children with explanations for their actions. Explanations provide children with a sense of awareness and understanding of their parents' values, morals, and goals. The transmission of these goals and values equips these students with the tools needed to perform well in school. Third, he suggests that authoritative parents engage in bidirection communication with their children. This communication style nurtures skills in interpersonal relations and produces better adjusted and more popular children. These interpersonal skills, he suggests, helps children succeed in school, both socially and academically.

Despite the reasons cited by Durkin (1995) above, research has shown that the relationship between authoritative parenting and school achievement is not consistent across families from diverse ethnic and socioeconomic backgrounds. Several studies, for example, have found differences for African American, Hispanic, and Asian children. Specifically, Baumrind (1972) found that authoritarian parenting, although eliciting fear and compliance in White children, elicited assertiveness in African American females. Dornbusch et al. (1987) found that authoritative parenting was associated with GPA for White families but not for Asian, Black, or Hispanic families. The researchers also found that authoritarian parenting was negatively associated with GPA for Asian and White families but not for Black or Hispanic families. In another study, Steinberg et al. (1992) found that authoritative parenting was highly correlated with adolescent GPA and engagement in school with two notable exceptions: (1) for African American adolescents, there was no relationship between authoritative parenting and adolescent achievement and engagement; (2) for Hispanic adolescents, authoritarian parenting was highly related to adolescent engagement, whereas the effect was relatively weak for other subgroups.

Research has suggested that socioeconomic status might play a role in the relationship between parenting styles and adolescent achievement. For 
example, Kelly et al. (1992) examined parental disciplinary styles and attitudes in a sample of low-income African American mothers. A total of 42 mothers were interviewed about their parenting disciplinary styles, the goals they hold for their children, the fears they have about crime in their neighborhood, and the fears they have about their child exhibiting antisocial behavior. The researchers found that parental education and number of parents in the home were related to parental disciplinary practices. Specifically, younger, less educated mothers, who were raising their child alone, were more likely to emphasize obedience (i.e., authoritarian) than parents who were older, educated, and raising their child in a two-parent family. These results suggest that socioeconomic factors play a role in parental disciplinary styles.

Research has also suggested that culture plays a role in the relationship between parenting styles and adolescent achievement. For example, Leung et al. (1998) examined the influence of parenting styles on children's academic achievement in four countries (United States, Hong Kong, China, and Australia). To measure parenting styles, Leung et al. adapted the survey items used to measure parenting styles by Dornusch and his colleagues (1987). They found that authoritarian parenting was negatively related to academic achievement in all countries except Hong Kong. There, authoritarian parenting was related positively to academic achievement. The researchers also found differences in the relationship between authoritarian parenting and adolescent academic achievement for parents with little education. Specifically, for low educated parents in the United States and Australia, authoritarian parenting was positively related to academic achievement.

\section{THE CONTEXTUAL MODEL OF PARENTING: AN ANALYSIS OF THE EMPIRICAL SUPPORT FOR ITS MAJOR TENETS}

In response to the literature suggesting that parenting styles are related to varied school-related outcomes in children, depending on the particular culture and context in which the family resides, Darling and Steinberg (1993) proposed the contextual model of parenting. The contextual model of parenting suggests that the socialization goals parents hold for their children (e.g., to attend college) lead to different types of parenting practices (e.g., parents helping with homework, parents monitoring after-school activities), which in turn facilitate adaptive adolescent school outcomes (e.g., high levels of school motivation, grade point average). For example, the model contends that parents who have aspirations for their children to perform well in school are more likely than parents who do not have 
these aspirations to monitor their children's after-school activities and get involved with their children's educational experiences. Furthermore, the model advocates viewing parenting style as a context (i.e., emotional climate) in which parental socialization goals are emphasized and parenting practices are exhibited. Therefore, the model suggests that parenting styles moderate the relationship between parenting practices and adolescent outcomes such that parents exhibiting a warm versus critical style while doing homework with their child would yield different outcomes.

There are at least three ways that the contextual model of parenting can be used as a framework to generate hypotheses about why authoritative parenting has not been related to high levels of adolescent academic achievement across all families. The first possibility is that parents of different ethnicities hold unique educational aspirations, goals, and values for their children, and therefore enact distinct parenting practices. A second possibility is that socioeconomic status (SES) moderates the relationship between parental socialization goals for their children and parental practices. For example, low SES parents, who might have similar school-related goals, aspirations, and values for their children as high SES parents, might lack the educational resources and the time (i.e., due to long work hours and higher prevalence of single parent families) to get involved with and monitor their child's school-related activities and progress. If so, parental practices would affect adolescent outcomes differentially as a function of SES. A third possibility is that parenting styles serve as a moderator between parenting practices and adolescent outcomes, resulting in distinct outcomes depending upon the combinations of parenting styles and practices. A review of the empirical research to support each of these potential mechanisms for explaining the discrepancies in the literature is presented below.

\section{Parental Socialization Goals: Do They Vary by Ethnicity?}

The contextual model of parenting uses parental socialization goals and values as the point of departure in the parental socialization system (see Darling and Steinberg, 1993). A key tenet of the contextual model is that parents' socialization goals influence their parenting practices. This tenet suggests, for example, that parents who prioritize their children's school achievement are more likely to enact practices (e.g., helping with homework, attending parent-teacher conferences) that correspond to this socialization goal than parents who do not prioritize their children's school achievement. Should this tenet hold true, parents with the same parenting style but different socialization goals will enact unique parenting practices 
that yield distinct outcomes in their children. As a result, this tenet could provide a possible explanation for the discrepant findings in the parenting styles and adolescent achievement literature.

If variations in parental socialization goals provide an explanation for the discrepancies in the literature, an important next step is to determine the parental and family characteristics associated with different socialization goals. Ogbu (1981) suggests that parental socialization goals might vary due to different societal demands faced by families. Specifically, he contends that parents define competence and socialize their children differently depending on the culture in which the family resides. Similarly, Bronfenbrenner's Ecological Systems Theory (1989) suggests that the larger cultural context, which he calls the macrosystem, influences the interface of the adolescent's family and school contexts (i.e., mesosystem). Should particular characteristics such as family ethnicity play a role in the formation of parental socialization goals, or play a role elsewhere in the model, the contextual model of parenting would benefit from expanding its notion of context to include the larger cultural context.

A review of the research on parental socialization goals with respect to academic achievement, however, suggests that these goals do not vary dramatically by ethnicity (De La Rosa and Maw, 1990; Muller and Kerbow, 1993; Stevenson et al., 1990; Spera and Wentzel, in press; Wentzel, 1998). For example, Stevenson et al. (1990) found that both nonminority and minority parents highly value school and have high aspirations for their children. In fact, Wentzel (1998) found that African American parents reported stronger achievement values and educational aspirations for their children than Caucasian parents. These findings do not support a hypothesis that parental socialization goals vary by ethnicity.

\section{Does SES Moderate the Relationship Between Parental Socialization Goals and Practices?}

If parental socialization goals do not differ by ethnicity, family SES might, however, influence parents' ability to enact parental practices consistent with their goals. For example, it is possible that parents from low SES backgrounds have achievement goals for their children similar to parents from high SES backgrounds; however, low SES parents might be faced with juggling multiple jobs and therefore might not have the time or resources to enact parenting practices that correspond to their socialization goals. Should future empirical research support this hypothesis, expanding the contextual model of parenting to include the larger socioeconomic context seems warranted. 
Although this hypothesis has not been tested, research has shown that SES influences parenting practices (see Hoff et al., 2002). For example, low SES parenting is associated with higher levels of harsh punishment of their children (Simons et al., 1991) and lower levels of parental involvement (Luster et al., 1989). Specifically, in the Value of Children Study, Hoffman et al. (1987) found that in families where the parents worked in a low SES job (e.g., manual or service sectors), these parents had a higher likelihood of enforcing strict rules than parents who worked in professional or managerial jobs. In a study by the U.S. Department of Education (1998), researchers found that $25 \%$ of schools reported that cultural and socioeconomic factors were a major reason for low levels of parental involvement.

Although the studies cited above provide theoretical support for the influence of SES on the parenting practices, they do not provide a clear picture of whether SES moderates the relationship between parental socialization goals and practices. Only one early study supports the possibility that childrearing goals and parenting practices are more closely linked for high SES parents than for low SES parents (Tulkin and Cohler, 1973). Future research should examine whether SES moderates the relationship between parental socialization goals and parental practices. Knowing this would determine how the larger socioeconomic context plays a role in the parental socialization of school achievement.

\section{Does Parenting Style Moderate the Relationship Between Parenting Practices and Adolescent Outcomes?}

Another primary tenet of the contextual model of parenting is that parenting styles moderate the relationship between parenting practices and child outcomes (see Darling and Steinberg, 1993). This suggests, for example, that parents who monitor their children's homework under an authoritative parenting style (high levels of responsiveness and demandingness) likely facilitate their children's school performance. Parents who monitor their children's homework under a parenting style that is authoritarian (low level of responsiveness and high level of demandingness), however, likely inhibit their children's school performance.

Although Darling and Steinberg (1993) viewed parenting styles as a primary contextual variable, little research to date has examined whether parenting styles actually moderate the relationship between parenting practices and adolescent outcomes. It should be noted, however, that a few studies have found that the relationship between parental involvement practices and high school achievement is strongest for students with authoritative parents (Paulson et al., 1998; Steinberg et al., 1992). Therefore, to better 
understand the parental socialization process, future research should examine the possibility that parenting styles moderate the relationship between parenting practices and adolescent achievement.

\section{CONCLUSION}

In conclusion, the research reviewed indicates that parents have a significant influence on the school achievement of their children. In terms of parenting practices, the research suggests that when parents are involved in their children's education and monitor their children's after-school activities, they facilitate their children's academic achievement and educational attainment. Several studies, however, report a decline in parental involvement during the middle school years. This raises important questions about why parental involvement in adolescence is declining and whether this decline has a deleterious impact on children. Researchers have suggested that the decline stems from parents' recognition of an increased need for adolescents to express their autonomy, however, it remains unclear whether parents can provide autonomy to their children while remaining involved in their children's educational pursuits. As a result, future research on parental school involvement and its potential decline during adolescence is warranted.

In terms of parenting styles, the research indicates that authoritative parenting styles are associated with higher levels of adolescent school achievement. Several studies, however, have concluded that these findings are not consistent across ethnicity, culture, and socioeconomic status. In an effort to help explain the discrepancies, Darling and Steinberg (1993) proposed a contextual model of parenting that suggests that parenting style is a context (i.e., emotional climate) in which parental socialization goals are emphasized and parental practices are exhibited.

Darling and Steinberg's (1993) model provides three ways to help explain the discrepancies in the literature. The first possibility is that parents of different ethnicities hold unique educational aspirations, goals, and values for their children, and therefore enact unique parenting practices. Research indicates, however, that parental aspirations, values, and goals for their children do not vary dramatically by ethnicity. A second possibility is that socioeconomic status moderates the relationship between parental socialization goals for their children and parental practices. Evidence to support this hypothesis would suggest that the contextual model should expand its notion of context toward the larger cultural and economic context in which families reside. Although this hypothesis seems plausible, little research to date has examined its potential moderating effect. Finally, a third 
possibility is that parenting styles serve as a moderator between parenting practices and adolescent outcomes, resulting in distinct outcomes dependent upon the combinations of parenting styles and practices. Similarly, little research to date has examined this hypothesis.

As a result, Darling and Steinberg's (1993) contextual model of parenting provides a promising model to help resolve the discrepancies in the literature on the relationship between parenting styles and adolescent achievement. Although the model has had a significant impact on the field, aspects of the model require further examination as to whether they can help explain the discrepancies in the literature. Therefore, further examination of the major linkages in the contextual model of parenting is warranted in order to increase knowledge of the parental socialization process.

\section{ACKNOWLEDGMENT}

The author acknowledges Dr. Kathryn R. Wentzel, University of Maryland, for her thoughtful comments on earlier versions of this manuscript, as reflected in the author's doctoral dissertation.

\section{REFERENCES}

Astone, N. M., and McLanahan, S. S. (1991). Family structure, parental practices, and high school completion. Am. Sociol. Rev. 56: 309-320.

Austin, J. T., and Vancouver, J. B. (1996). Goal constructs in psychology: Structure, process, and content. Psychol. Bull. 120: 338-375.

Baldwin, A. L. (1948). Socialization and the parent-child relationship. Child Dev. 19: 127136.

Bandura, A. (1989). Social cognitive theory. In Vasta, R. (ed.), Annals of Child Development, JAI, Greenwich, CT, pp. 1-60.

Baumrind, D. (1967). Child care practices anteceding three patterns of preschool behavior. Gene. Psychol. Monogr. 75: 43-88.

Baumrind, D. (1971). Current patterns of parental authority. Dev. Psychol. Monogr. 4: 1103.

Baumrind, D. (1972). An exploratory study of socialization effects on Black children: Some Black-White comparisons. Child Dev. 43: 261-267.

Baumrind, D. (1978). Parental disciplinary patterns and social competence in children. Youth Soc. 9: 239-276.

Baumrind, D. (1989). Rearing competent children. In Damon, W. (ed.), Child Development Today and Tomorrow, Jossey-Bass, San Francisco, pp. 349-378.

Baumrind, D. (1991). Parenting styles and adolescent development. In Brooks-Gunn, J., Lerner, R., and Peterson, A. C. (eds.), The Encyclopedia of Adolescence, Garland, New York, pp. 746-758.

Becker, W. C. (1964). Consequences of different kinds of parental discipline. In Hoffman, M. L., and Hoffman, L. W. (eds.), Review of Child Development Research, Vol. 1, Russell Sage Foundation, New York, pp. 169-208.

Becker, H. J., and Epstein, J. L. (1982). Parent involvement: A study of teacher practices. Element. School J. 83: 85-102. 
Bronfenbrenner, U. (1979). The Ecology of Human Development: Experiments by Nature and Design, Harvard University Press, Cambridge, MA.

Bronfenbrenner, U. (1989). Ecological systems theory. In Vasta, R. (ed.), Annals of Child Development, JAI, Greenwich, CT, pp. 187-249.

Clark, R. M. (1993). Homework-focused parenting practices that positively affect student achievement. In Chavkin, N. F. (ed.), Families and Schools in a Pluralistic Society, State University of New York Press, Albany, pp. 85-105.

Crandall, V., Dewey, R., Katkovsky, W., and Preston, A. (1964). Parents' attitudes and behaviors and grade school children's academic achievement. J. Gene. Psychol. 104: $53-$ 66.

Darling, N., and Steinberg, L. (1993). Parenting style as context: An integrative model. Psychol. Bull. 113: 487-496.

De La Rosa, D., and Maw, C. E. (1990). Hispanic Education: A Statistical Portrait 1990, National Council of La Raza, Washington, DC.

Dornbusch, S. M., Ritter, P. L., Leiderman, P. H., Roberts, D. F., and Fraleigh, M. J. (1987). The relation of parenting style to adolescent school performance. Child Dev. 58: 12441257.

Durkin, K. (1995). Developmental Social Psychology: From Infancy to Old Age, Blackwell, Malden, MA.

Eccles, J. S., and Wigfield, A. (1995). In the mind of the achiever: The structure of adolescents' academic achievement related beliefs and self-perceptions. Pers. Soc. Psychol. Bull. 21: 215-225.

Eccles (Parsons), J. S., Adler, T. F., Futterman, R., Goff, S. B., Kaczala, C. M., Meece, J. L., and Midgley, C. (1983). Expectancies, values, and academic behaviors. In Spence, J. T. (ed.), Achievement and Achievement Motivation, Freeman, San Francisco, CA.

Entwisle, D. R., and Hayduk, L. A. (1982). Early Schooling: Cognitive and Affective Outcomes, Johns Hopkins University Press, Baltimore, MD.

Epstein, J. L. (1996). Perspectives and previews on research and policy for school, family, and community partnerships. In Booth, A., and Dunn, J. F. (eds.), Family-School Links: How do They Affect Educational Outcomes?, Erlbaum, Mahwah, NJ.

Epstein, J. L., and Dauber, S. L., (1991). School programs and teacher practices of parent involvement in inner-city elementary and middle schools. Element. School J. 91: 289305 .

Epstein, J. L., and Connors, L. J. (1994). School and family partnerships in the middle grades. In Rutherford, B. (ed.), Creating Family/School Partnerships, National Middle School Association, Columbus, $\mathrm{OH}$.

Epstein, J. L., and Lee, S. (1995). National patterns of school and family connections in the middle grades. In Ryan, B. A., Adams, G. R., Gullotta, T. P., Weissberg, R. P., and Hampton, R. L. (eds.), The Family-School Connection: Theory, Research, and Practice, Sage, Thousand Oaks, CA, pp. 108-154.

Epstein, J. L., and Sanders, M. G. (2002). Family, school, and community partnerships. In Bornstein, M. H. (ed.), Handbook of Parenting. Vol. 5: Practical Issues in Parenting, Erlbaum, Mahwah, NJ, pp. 407-437.

Ford, M. (1992). Motivating Humans: Goals, Emotions, and Personal Agency Beliefs, Sage, Newbury Park, CA.

Freud, S. (1933). New Introductory Lectures in Psychoanalysis, Norton, New York.

Goldenberg, C. (1987). Low income Hispanic parents' contribution to their first-grade children's word-recognition skills. Anthropol. Educ. Q. 18: 149-179.

Greenwood, G. E., and Hickman, C. W. (1991). Research and practice in parent involvement. Implications for teacher involvement. Element. School J. 91: 279-288.

Grusec, J. E. (2002). Parenting socialization and children's acquisition of values. In Bornstein, M. H. (ed.), Handbook of Parenting: Vol. 5: Practical Issues in Parenting, Erlbaum, Mahwah, NJ, pp. 143-167.

Grusec, J. E. (1997). A history of research on parenting strategies and children's internalization of values. In Grusec, J. E., and Kuczynski, L. (eds.), Parenting and Children's Internalization of Values: A Handbook of Contemporary Theory, Wiley, New York, pp. 3-22. 
Grusec, J. E., Dix, T., and Mills, R. (1982). The effects of type, severit and victim of children's transgressions on maternal discipline. Can. J. Behav. Sci. 14: 276-289.

Grusec, J. E., Goodnow, J. J., and Kuczynksi, L. (2000). New directions in analyses of parenting contributions to children's acquisition of values. Child Dev. 71: 205211.

Harter, S. (1983). Development perspectives on the self-system. In Hetherington, E. M. (ed.), Mussen, P. H. (Series ed.), Handbook of Child Psychology: Vol. 4. Socialization, Personality, and Social Development, Wiley, New York, pp. 275-385.

Hess, R. D., and Holloway, S. D. (1984). Family and school as educational institutions. In Parke, R. D. (ed.), Review of Child Development Research, Vol. 7, University of Chicago Press, Chicago, pp. 179-222.

Hewison, J. (1988). The long-term effectiveness of parental involvement in reading: A followup to the Haringey Reading Project. Br. J. Educ. Psychol. 58: 184-190.

Hill, N. E. (2001). Parenting and academic socialization as they relate to school readiness: The role of ethnicity and school income. J. Educ. Psychol. 93: 686-697.

Hill, N. E., Castellino, D. R., Lansford, J. E., Nowlin, P., Dodge, K. A., Bates, J. E., and Pettit, G. S. (in press). Associations among parent-school involvement, school behavior, achievement, and aspirations: A longitudinal study.

Hill, N. E., and Taylor, L. C. (2004). Parent-school involvement and children's academic achievement: Pragmatics and issues. Curr. Direct. Psychol. Sci. 13: 161-164.

Hodgkinson, H. L. (1992). A Demographic Look at Tomorrow, Institute for Educational Leadership, Washington, DC.

Hoff, E., Laursen, B., and Tardif, T. (2002). Socioeconomic status and parenting. In Bornstein, M. H. (ed.), Handbook of Parenting: Second Addition, Erlbaum, Mahwah, NJ.

Hoffman, M. L. (1970). Moral development. In Mussen, P. H. (ed.), Carmichael's Manual of Child Psychology, Vol. 2, Wiley, New York, pp. 261-360.

Hoffman, M. L. (1983). Affective and cognitive processes in moral internalization: An information processing approach. In Higgins, E. T., Ruble, D., and Hartup, W. (eds.), Social Cognition and Social Development: A Sociocultural Perspective, Cambridge University Press, Cambridge, England, pp. 236-274.

Hoffman, L. W., McManus, K. A., and Brackbill, B. (1987). The value of children to young and elderly parents. Int. J. Aging Hum. Dev. 25: 309-322.

Hoover-Dempsey, K. V., Bassler, O. C., and Brissie, J. S. (1987). Parent involvement: Contributions of teacher efficacy, school socioeconomic status, and other school characteristics. Am. Educ. Res. J. 24: 417-435.

Kao, G., and Tienda, M. (1995). Optimism and achievement: The educational performance of immigrant youth. Soc. Sci. Q. 76: 1-19.

Keeves, J. P. (1972). Educational environment and student achievement. Stockholm Stud. Educ. Psychol. 20: 1-309.

Kelley, M. L., Power, G. T., and Wimbush, D. D. (1992). Determinants of disciplinary practices in low-income Black mothers. Child Dev. 63: 573-582.

Keith, T. Z., Reimers, T. M., Fehrmann, P. G., Pottebaum, S. M., and Aubey, L. W. (1986). Parental involvement, homework, and TV time: Direct and indirect effects on high school achievement. J. Educ. Psychol. 78: 373-380.

Kreppner, K. (1992). Developing in a developing context: rethinking the family's role for children's development. In Winegar, L. T., and Valsiner, J. (eds.), Children's Development Within Social Context, Erlbaum, Hillsdale, NJ.

Lamborn, S. D., Mounts, N. S., Steinberg, L., and Dornbusch, S. M. (1991). Patterns of competence and adjustment among adolescents from authoritative, authoritarian, indulgent, and neglectful families. Child Dev. 62: 1049-1065.

Ladd, G. W., and Pettit, S. (2002). Parenting and the development of children's peer relationships. In Bornstein, M. H. (ed.) Handbook of Parenting: Vol. 5: Practical Issues in Parenting, Erlbaum, Mahwah, NJ, pp. 269-309.

Lee, C. C. (1985). Successful rural Black adolescents: A psychological profile. Adolescence 20: 129-142. 
Leung, K., Lau, S., and Lam, W. (1998). Parenting styles and academic achievement: A crosscultural study. Merrill-Palmer Q. 44: 157-167.

Locke, J. (1689). Essay Concerning Human Understanding, Macmillan, New York.

Luster, T., Rhoades, K., and Haas, B. (1989). The relation between parental values and parenting behavior: A test of the Kohn hypothesis. J. Marriage Fam. 51: 139-147.

Maccoby, E. E., and Martin, J. A. (1983). Socialization in the context of the family: Parentchild interaction. In Mussen, P. H. (Series ed.) and . Heatherington, E. M. (Vol. ed.), Handbook of Child Psychology: Vol. 4. Socialization, Personality, and Social Development, Wiley, New York.

Milgram, N., and Toubiana, Y. (1999). Academic anxiety, academic procrastination, and parental involvement in students and their parents. Br. J. Educ. Psychol. 69: 345-361.

Muller, C. (1993). Parental involvement and academic achievement: An analysis of family resources available to the child. In Schneider, B., and Coleman, J. S. (eds.), Parents, Their Children, and Schools, Westview, Boulder, CO, pp. 73-113.

Muller, C. (1998). Gender differences in parent involvement and adolescents' mathematics achievement. Sociol. Educ. 71: 336-356.

Muller, C., and Kerbow, D. (1993). Parent involvement in the home, school, and community. In Schneider, B., and Coleman, J. S. (eds.), Parents, Their Children, and Schools, Westview, Boulder, CO, pp. 13-39.

Ogbu, J. (1981). Origins of human competence: A cultural-ecological perspective. Child Dev. 52: 413-429.

Parke, R. D., and Buriel, R. (1998). Socialization in the family: Ethnic and ecological perspectives. In Damon, W. (Series ed.) and Eisenberg, N. (Vol. ed.), Handbook of Child Psychology: Vol. 3. Social, Emotional, and Personality Development, Wiley, New York.

Paulson, S. E. (1994). Relations of parenting style and parental involvement with ninth-Grade students' achievement. J. Early Adolesc. 14: 250-267.

Paulson, S. E., Marchant, G. J., and Rothilsberg, B. A. (1998). Early adolescents' perceptions of patterns of parenting, teaching, and school atmosphere: Implications for achievement. J. Adolesc. 18: 5-26.

Prom-Jackson, S. (1987). Home environment, talented minority youth, and school achievement. J. Negro Educ. 56: 111-121.

Pugh, M. D. (1976). Statistical assumptions and social reality: A critical analysis of achievement models. Sociol. Educ. 49: 34-40.

Richardson, R. L., and Gerlach, S. C. (1980). Black dropouts: A study of significant factors contributing to a black student's decision. Urban Educ. 14: 489-494.

Rogers, C. R. (1960). A Therapist's View of Personal Goals (Pendle Hill Pamphlet No. 108), Pendle Hill, Wallingford, PA.

Rousseau, J. J. (1762). The Social Contract, Penguin Books, London.

Ryan, B. A., and Adams, G. R. (1995). The family-school relationships model. In Ryan, B. A., Adams, G. R., Gullotta, T. P., Weissberg, R. P., and Hampton, R. L. (eds.), The FamilySchool Connection: Theory, Research, and Practice, Sage, Thousand Oaks, CA, pp. $3-$ 28.

Ryan, R. M., and Stiller, J. (1991). The social contexts of internalization: Parent and teacher influences on autonomy, motivation, and learning. In Maehr, M. L., and Pintrich, P. L. (eds.), Advances in Motivation and Achievement, Vol. 7, JAI, Greenwich, CT, pp. 115149.

Scaringello, F. (2002). Creating computerized communication linkages with parents: The future is now. In McAuliffe, G. (ed.), Working with Troubled Youth in Schools: A Guide for all School Staff, Bergin \& Garvey, Westport, CT, pp. 125-131.

Schaefer, E. S. (1959). A circumplex model of maternal behavior. J. Abnorm. Soc. Psychol. 59: 226-235.

Scott-Jones, D. (1995). Parent-child interactions and school achievement. In Ryan, B. A., Adams, G. R., Gullotta, T. P., Weissberg, R. P., and Hampton, R. L. (eds.), The FamilySchool Connection: Theory, Research, and Practice, Sage, Thousand Oaks, CA, pp. 75107. 
Sears, R. R., Macoby, E., and Levin, H. (1957). Patterns of Child Rearing, Row, Peterson, Evanston, IL.

Seginer, R. (1983). Parents' educational expectations and children's academic achievements: A literature review. Merril-Palmer Q. 29: 1-29.

Simmons, R. G., Burgeson, R., Carlton-Ford, S., and Blyth, D. A. (1987). The impact of cumulative changes in early adolescence. Child Dev. 58: 1220-1234.

Simons, R. L., Whitbeck, L. B., Conger, R. D., and Chyi-In, W. (1991). Intergenerational transmission of harsh parenting. Dev. Psychol. 27: 159-171.

Soloranzo, D. G. (1992). An exploratory analysis of the effects of race, class, and gender on student and parent mobility aspirations. J. Negro Educ. 61: 30-44.

Spera, C., and Wentzel, K. R. (in press). Parental educational aspirations for their children: The relation of ethnicity, parent education, GPA, and school-related factors. Manuscript in preparation.

Steinberg, L. (1990). Autonomy, conflict, and harmony in the family relationship. In Feldman, S., and Elliot, G. (eds.), At the Threshold: The Developing Adolescent, Harvard University Press, Cambridge, MA, pp. 255-276.

Steinberg, L., Elmen, J. D., and Mounts, N. S. (1989). Authoritative parenting, psychosocial maturity, and academic success among adolescents. Child Dev. 60: 1425-1436.

Steinberg, L., Lamborn, S., Dornbusch, S., and Darling, N. (1992). Impact of parenting practices on adolescent achievement: Authoritative parenting, school involvement, and encouragement to succeed. Child Dev. 63: 1266-1281.

Steinberg, L., Mounts, N. S., Lamborn, S. D., and Dornbusch, S. M. (1991). Authoritative parenting and adolescent adjustment across varied ecological niches. J. Res. Adolesc. 1: $19-36$.

Steinberg, L. and Silk, X. (2002). Parenting adolescents. In Bornstein, M. H. (ed.), Handbook of Parenting: Vol. 1: Children and Parenting, Erlbaum, Mahwah, NJ, pp. 103-133.

Stevenson, D. L., and Baker, D. P. (1987). The family-school relation and the child's school performance. Child Dev. 58: 1348-1357.

Stevenson, H. W., Chen, C., and Uttal, D. H. (1990). Beliefs and achievement: A study of Black, White, and Hispanic children. Child Dev. 61: 508-523.

Symonds, P. M. (1939). The Psychology of Parent-Child Relationships, Appleton-CenturyCrofts, New York.

Tulkin, S. R., and Cohler, B. J. (1973). Childrearing attitudes and mother-child interaction in the first year of life. Merrill-Palmer Q. 19: 95-106.

U.S. Bureau of Census (2004). Educational Attainment in the United States: 2003, U.S. Bureau of Census, Washington, DC.

U.S. Department of Education, National Center for Educational Statistics (1998). Factors Associated With Father's and Mother's Involvement in Their Children's Schools, U.S. Department of Education, Washington, DC.

Wentzel, K. R. (1998). Parents' aspirations for children's educational attainments: Relations to parental belief systems and social address variables. Merrill-Palmer Q. 44: 20-37.

Wentzel, K. R. (1999). Social-motivational processes and interpersonal relationships: Implications for understanding students' academic success. J. Educ. Psychol. 91: 76-97.

Wentzel, K. R., and Battle, A. A. (2001). School relationships and school adjustment. In Urdan, T., and Pajares, F. (eds.), Adolescence and Education: General Issues in the Education of Adolescence, Information Age Publishing, Greenwich, CT, pp. 93-118.

Wigfield, A. (1993). Why should I learn this? Adolescents' achievement values for different activities. Adv. Motivat. Achiev. 8: 99-138. 